\title{
Correction to: Disruption of brain conductivity and permittivity and neurotransmitters induced by citrate-coated silver nanoparticles in male mice
}

\author{
Azza Attia ${ }^{1} \cdot$ Heba Ramadan ${ }^{2} \cdot$ Reda ElMazoudy ${ }^{3,4}$ (D) Asmaa Abdelnaser $^{5}$ \\ Published online: 6 April 2021 \\ (C) Springer-Verlag GmbH Germany, part of Springer Nature 2021
}

\section{Correction to: Environmental Science and Pollution Research} https://doi.org/10.1007/s11356-021-13397-5

The original publication of this paper contains a mistake.

In the title the last word rats was changed to mice.

Publisher's note Springer Nature remains neutral with regard to jurisdictional claims in published maps and institutional affiliations.

The online version of the original article can be found at https://oi.org/ $10.1007 / \mathrm{s} 11356-021-13397-5$
Azza Attia
azzaaattia@hotmail.com
$\bowtie$ Reda ElMazoudy
rhelmazoudy@alexu.edu.eg

1 Zoology Department, Faculty of Science, Alexandria University, P.O. Box. 21511, Moharram Bek, Alexandria, Egypt

2 Biophysics Department, Medical Research Institute, Alexandria University, Alexandria, Egypt

3 Biology Department, College of Science, Imam Abdulrahman Bin Faisal University, P.O. Box. 1982, Dammam 31441, Saudi Arabia

4 Basic and Applied Scientific Research Center, Imam Abdulrahman Bin Faisal University, P.O. Box. 1982, Dammam 31441, Saudi Arabia

5 Department of Biomedical Sciences, Pharos University, Smouha, Alexandria, Egypt 